\begin{tabular}{ccc}
\hline International Journal of Engineering \& Technology \\
SPC & Website: $\frac{\text { www.sciencepubco.com/index.php/IJET }}{\text { Research paper }}$ \\
\hline
\end{tabular}

\title{
An Assessment of Water and Sediment Quality of River in India with Special Reference to Pesticide Contamination, a Case Study
}

\author{
Divya.A.H ${ }^{1 *}$, P.A. Soloman ${ }^{2}$ \\ ${ }^{1}$ Chemical Engineering Dept., Govt. Engineering College, Thrissur \\ ${ }^{2}$ Chemical Engineering Dept., Govt .Engineering College, Thrissur \\ *Corresponding author E-mail divyaprajeen2@gmail.com:
}

\begin{abstract}
Drinking water quality has become a serious issue in many countries due to the scarcity of fresh water resources. Water quality monitoring is the first step for the management and conservation of aquatic system. The contamination of OrganoChlorine Pesticides (OCPs) is very harmful for the environment and human beings. The presence of OCPs in surface water and in the bottom sediment in the Chalakudy River was investigated to evaluate the pollution load and distribution level of OCP seasonally over a period of 3 years from January 2013 to December 2015. Surface water sample and bottom sediment were collected from nine different sites (upstream, midstream and downstream) and analyzed for their profile of important physicochemical parameters and for persistence of OCP. To know the present trends in the river clearly ,temporal distribution and spatial distribution of OCPs and other parameters are studied based on three season(winter, summer, and monsoon). Obtained trend in each year were compared through sampling and analysis.
\end{abstract}

Keywords: Chalakudy River; Organochlorine Pesticides; Physico Chemical parameters; Sediment

\section{Introduction}

Chalakudy River is the fourth longest river in Kerala and the longest river in Thrissur district having the length $144 \mathrm{~km}$. The total drainage area is $1704 \mathrm{sq} \mathrm{km}$, out of which $1404 \mathrm{sq} \mathrm{km}$ is in Kerala and the rest $300 \mathrm{sq} \mathrm{km}$ in Coimbatore district of Tamil Nadu. It originates from the Anamalais and Nelliampathy ranges of the Western Ghats. In Kerala it flows westward through the Palakkad, Thrissur and Ernakulam districts. A major portion lies in the Thrissur district. When coming to the plains it joins with the northern distributaries of Periyar, the largest river in Kerala at a place called Elanthikkara, just $9 \mathrm{~km}$ before they together end in the Lakshadweep Sea at Kodungallur estuary [12]. Chalakudy River is one of the most important river and water sources of domestic, agricultural and industrial usage in Thrissur and Palakkad Districts in Kerala This River is flowing through 29 panchayaths in which 27 are in Thrissur district and 2 in Palakkad District.

The common use of pesticides is in the area of agriculture, public health sector to eradicate the various pests and diseases which affect the humanity. The entry of Pesticides into the environment is either by agricultural runoff, by accident or by misuse. Direct contamination may occur from pesticide spills, back siphoning, improper storage and disposal of pesticide containers. Pesticides are used by wide spectrum of users such as individuals, companies, municipalities etc. These non biodegradable pollutants can enter the food chains and become more concentrated at high tropic levels by biomagnifications and adversely affect the entire ecosystem. The pesticides once released into the environment can remain indefinitely in sediment or in atmosphere, which finally reaches in the water bodies [3]. When they reach on the ground, it continues to breakdown, usually much slower than in surface layers of soil
[11]. Neurological and reproductive damage, cancer, growth and development of birth defects, endocrine disruptions etc. are the chronic pesticide effects on human health. Therefore pesticide analysis in river water and resources of potable water should be a great concern.

The factors affecting the POPs in water are bottom sediment, $\mathrm{pH}$, solubility, temperature and presence of organic matter. The pesticides having important role in connection with river water quality include soil insecticides, persistence herbicide, chlorinated hydrocarbons and its derivatives. In these compounds chlorinated hydrocarbons persists environment and are known to have drifted over thousands of kilometers. Traces of organochlorine pesticides (OCPs) in water may accumulate progressively in different steps of food chain. Organochlorine pesticides have been extensively used in India for agricultural and public health purposes [13].

\subsection{Organochlorine Pesticides (OCPs)}

OCPs are strong long lasting, hydrophobic pesticides with low water solubility and frequently determined in natural water resources [6]. Organochlorine pesticides have extremely strong bonds between their chlorine and carbon components and are attracted to fats and highly insoluble in water. The problem with their strength is that once OCPs are used they can be around for a long time, in a human or animal body, in the water supply or in the soil. OCPs are widely used as insecticide. When used, OCPs can enter into our environment via direct application, contaminated waste disposal, incinerator emissions or runoff. These pesticides enter into human and animal bodies mainly via diet. Since OCPs don't breakdown easily in fatty tissue, this can cause persistent organic pollution [5]. OCPs are highly soluble in Hydrocarbons. It 
possesses high stability against degradation in the environment. Solubility in water is very low unless oxygen or nitrogen is present in the molecules and also the toxicity towards insects is relatively high.

\section{Materials and Methods}

\subsection{Study Area}

Fig.1. shows the map of Chalakudy river basin. The present study area starts from Vazhachal $(400 \mathrm{~m}$ above sea level) to Vynthala (Sea level). The length of the river studied is $60 \mathrm{~km}$ i.e. $41 \%$ of the total river length $(144 \mathrm{~km})$. The study is focused mainly on the quality of the river water and sediment. Nine sampling sites selected for monitoring the pollution load in the river. The site selection is decided in order to understand the effect of all major inflows [14]. A small scale paper mill was located near Kanjirappilly site, presently it is not working. One DCP (Dicalcium Phosphate) plant is located in Kathikudam (500m from Iyyathumkadavu). At the upstream of the sampling point Meloor, a famous distillery is working on the banks of the river.

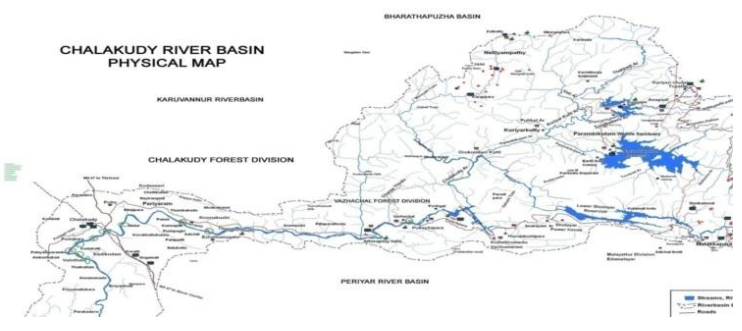

\subsection{Samples Collection}

Water samples were collected from 9 stations (given in table 1) during twice in a month using the grab sample method. Sample were collected in $1000 \mathrm{ml}$ HDPE bottles for determination of physico-chemical parameters except DO and OCP analysis. The plastic bottles were rinsed with $1 \mathrm{M} \mathrm{HCl}$ and then with distilled water. The bottles were also rinsed thrice with water sample before final collection. The collected samples were caped tightly and placed in a cooler box with ice for transportation to the laboratory [6]. DO bottles filled with water, with carefully the water must be added along the sides the sides of the bottle without entering air up to the brim and Stoppered it. The samples had to be stored in refrigerator at $4^{\circ} \mathrm{C}$ with preservation as appropriate analysis, when analysis was not done immediately upon arrival at the laboratory. Bottom Sediments were collected using iron mesh shovel at the described points to the depth of between 10 and 15 centimeters [7].

\begin{tabular}{ccc}
\multicolumn{2}{c}{ Table1: Sampling Stations } & \\
\hline $\begin{array}{c}\text { Site } \\
\text { code }\end{array}$ & Place & Activity \\
\hline I & Vazhachal & Tourist Spot,Forest division \\
II & Vettilappara & Water theme park, Agricultural area \\
III & Kanjirappilly & Paper mill \\
IV & Mellor & Bathing, Scroll Breweries \\
V & Chalakudy & Major Town, KWA Pumping Sta- \\
& tion \\
VI & Iyyathum kadavu & Downstream of DCP plant \\
VII & Mambrakadavu & Bathing, fishing, agriculture area \\
VIII & Palapuzhakadavu & Bathing, Residential area, agricul- \\
& & ture area \\
IX & Vynthala & KWA Drinking water pumping \\
& & station \\
\hline
\end{tabular}

\subsection{Analytical Procedure}

\subsubsection{Physico-Chemical Parameters Analyzed}

Surface water samples were analyzed for different physicochemical parameters. $\mathrm{pH}$ and $\mathrm{EC}$ were determined by electronic meters. Temperature was determined using $\mathrm{Hg}$ thermometer. TDS was measured by gravimetric method at $180^{\circ} \mathrm{C}$ (APHA $2540 \mathrm{C}$ ). Chloride was determined by argentometric method (APHA 4500$\mathrm{Cl}-\mathrm{B}$ ), Hardness as $\mathrm{CaCO}_{3}$ was determined by titration method (APHA 2340 C). DO by Winkler method (APHA 4500-O B C). Turbidity was measured by Nephelometer (APHA 2130 B), TC by membrane filter technique (APHA 922B) [9].

\subsubsection{Pesticide Analysis}

\section{a. Principle}

Chromatographic techniques are used for detection and determination of organic hazardous compounds like pesticide in environmentally relevant concentrations. The pesticide analysis was done as per the method APHA6630B using Gas Chromatograph (GC) Perkin Elmer clarus 500 model with a electron capture detector $(\mathrm{ECD})$ at $300^{\circ} \mathrm{C}$, column Elite $-5[30 \mathrm{~m} \times 0.53 \mathrm{~mm} \times 0.5 \mu \mathrm{m}]$, oven at $200^{\circ} \mathrm{C} / 5 \mathrm{~min}\left(5^{\circ} \mathrm{C} / \mathrm{min}\right.$ to $\left.220^{\circ} \mathrm{C}\right)$, injection port at $250^{\circ} \mathrm{C}, 4 \mathrm{psi}$ nitrogen (carrier gas) flow and $0.2 \mu$ liters of split less Injection. Detection limit of this equipment was $0.04 \mu \mathrm{g} / \mathrm{l}$. The instrument was calibrated using the standards of the components to be analyzed. The Retention Time (R.T) for the pesticides analyzed by the Gas Chromatograph is shown in Table2. Fig. 2 shows an example for the Chromatogram obtained for pp DDT in a sediment sample.

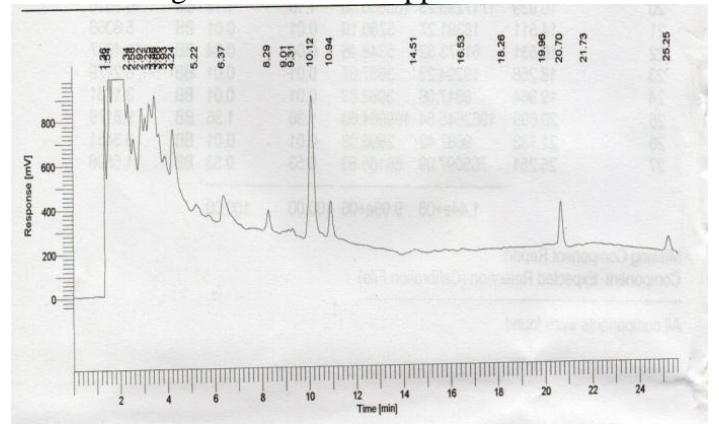

Figure 2: Example for Chromatogram obtained for a single sample

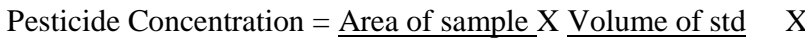
Area of std Volume sample injected Conc. of Std X Volume of sample extracted X dilution factor Volume of sample

\section{b. Standards and reagents}

The equipment has to be standardized and calibrated using the standards of the corresponding pesticides to be analyzed. Analytical reference grade standards as per APHA methods should be used.

\section{c. Extraction}

The pesticides should be extracted from the water and sediment samples using the suitable organic solvent. In this study we used hexane for extraction from water sample. Hexane and acetone is used for the extraction from sediment sample. $1 \mathrm{~L}$ of water sample mixed in a $2 \mathrm{~L}$ separating funnel followed by $25 \mathrm{ml}$ of $\mathrm{n}$-Hexane. By shaking thoroughly up to 5 minutes make it uniform and wait for phase separation. Collected the solvent and dehydration of total solvents was done by passing it through anhydrous sodium sulphate. This extract was analyzed using GC after distillation and concentrated in to $5 \mathrm{ml}$.For the analysis of sediment, soil sample was dried below $60^{\circ} \mathrm{c}$ using an Oven. $10 \mathrm{ml} \mathrm{n}$ hexane and $10 \mathrm{ml}$ acetone added in to $4 \mathrm{gm}$ fine sample and allow to mixing using Microwave digester (UV) about 30 minutes. By keeping degree of dilution ,inject $2 \mu \mathrm{l}$ sample from transparent solution in to the GC .The samples were stored at $+4^{\circ} \mathrm{C}$ and extraction of OCPs was performed within $48 \mathrm{~h}[9,10]$.

\section{Results and Discussion}

Some physico-chemical parameters of the water samples collected from 9 sites were analysed and compared with the values of BIS and WHO standards given in table 3. Spatial and temporal distributions of physico-chemical parameters in surface water and pres- 
ence of OCPs of Chalakudy River are graphically plotted. The presence of OCPs were identified and confirmed from the sample extract based on their retention time.

Fig. 3 shows the temporal and spatial distribution of the maximum temperature. The mean surface water temperature was $28.35^{\circ} \mathrm{C}$ with a standard deviation of \pm 1 .27. The highest temperature for the study area was $34^{\circ} \mathrm{C}$ in site I and in site III during Non monsoon 2014. But in 2015 the maximum temperature observed is $31^{\circ} \mathrm{C}$ in site III and in site IV. Lower temperature was $26^{\circ} \mathrm{C}$ in site IX during monsoon 2013. It was noticed that sunshine after a heavy rain can increase the water temperature. In this study it has been observed that highest surface water temperature was from March to June and lowest was from July to February. Many of the characteristics of waterways and growth of aquatic organisms are directly affected by the temperature [12].

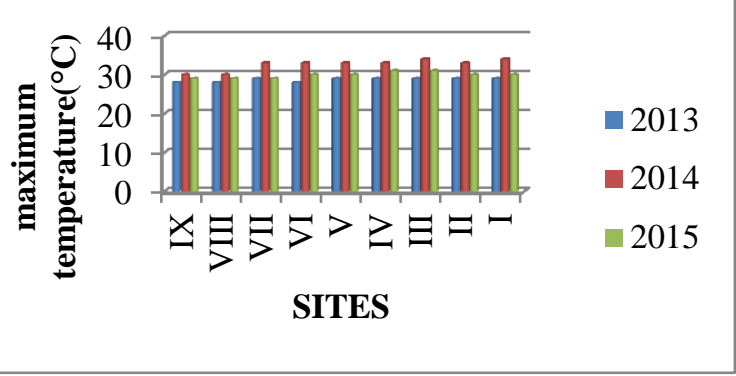

Fig 3. Spatial and temporal distribution of maximum temperature

Fig. $4 \mathrm{a}$ and $4 \mathrm{~b}$ shows the temporal and spatial distribution of the minimum and maximum $\mathrm{pH}$. Mean $\mathrm{pH}$ value obtained in the surface water during the study period was normally lies between the acceptable limit, 6.8 to 7.3. This is very good for culturing tropical fish species [14]. And this is also the recommended range of drinking water. But in some sites, significantly low value of $\mathrm{pH}$ (5.7 in siteVIII) and high value of $\mathrm{pH}$ (8.6 in site VIII and in Site VI) was observed during 2015 . The overall nature of water regarding $\mathrm{pH}$ of Site VIII, Site VII, and Site IX shows slightly alkaline during the study period. Minimum $\mathrm{pH}$ was observed during monsoon which could be related with low temperature, organic matter decomposition etc [13].

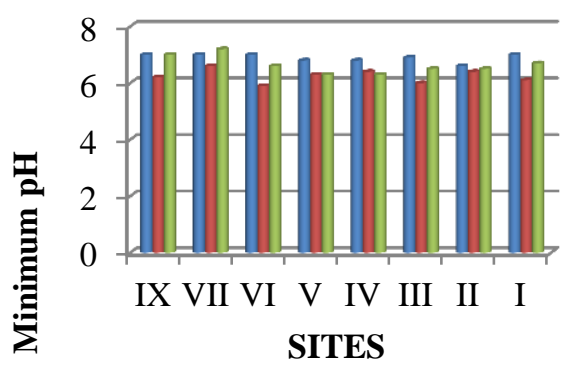

2013

Fig. 5 shows the temporal and spatial distribution of the maximum chlorides. The highest mean chloride concentration observed in this river during the study time is $38.65 \mathrm{mg} / \mathrm{l}$ during 2014 . The highest value of Chloride was shown in Site VII; the value was $200 \mathrm{mg} / \mathrm{l}$. Chloride values in the river ranges from $6-200 \mathrm{mg} / \mathrm{l}$. Seawater intrusion has been found to contain chloride at concentrations ranging from 5 to $460 \mathrm{mg} / \mathrm{l}$. The desirable limit proposed by Indian Standard for chloride is $250 \mathrm{mg} / \mathrm{l}$ [5].

Fig. 6 shows the temporal and spatial distribution of the maximum turbidity. The maximum turbidity observed was 13.6 NTU in site VI during monsoon 2013. Turbidity in some sites during monsoon was beyond the drinking water limit [5]. The turbidity values of this river during the study period ranges from $0.1 \mathrm{mg} / \mathrm{l}-13.6 \mathrm{mg} / \mathrm{l}$. Growth of phytoplankton may be caused the turbidity of river water[15]. Human activities like construction, mining and agriculture can lead to increase in suspended solids level entering water bodies during rain storms due to storm water runoff may be a cause of Turbidity. In the absence of alternate source, the allowable value of turbidity for drinking water is $10-25$ NTU.
Fig.7 shows the temporal and spatial distribution of the maximum hardness as $\mathrm{CaCo}_{3}$. During the study period hardness had a peak value of $144 \mathrm{mg} / \mathrm{l}$, a lowest value of $7 \mathrm{mg} / \mathrm{l}$ and a mean $\pm \mathrm{SD}$ of 23.67 \pm 12.18 . The maximum hardness observed in SiteV during non monsoon 2014 and minimum value observed is $7 \mathrm{mg} / \mathrm{L}$ during non monsoon 2014. Being a bathing ghat and due to the continuous use of soap and detergents, the water samples collected from Site IV were moderately hard ( 75 to $150 \mathrm{mg} / \mathrm{L}$ as $\mathrm{CaCO}_{3}$ ). The mean values of hardness were significantly different during monsoon 2014.

Fig $8 \mathrm{a}$ and Fig $8 \mathrm{~b}$ shows the temporal and spatial distribution of the maximum and minimum DO. DO is a very important factor for the occurrence of aquatic life. It is a function of physical and biological processes. More organisms can be found while the amount of available Oxygen is high, [6, 7]. River shows a range of values of DO from $6 \mathrm{mg} / \mathrm{l}-8.6 \mathrm{mg} / \mathrm{l}$. The maximum DO was observed in Vettilappara Site (Site II) during monsoon 2013. This might be due to the rainfall and fresh water inflow like water falls in to the river [8]. The minimum DO observed was $5.7 \mathrm{mg} / \mathrm{l}$ in site VI during summer 2014 and $6.8 \mathrm{mg} / \mathrm{L}$ in site III during summer 2015. In summer season minimum flow in the stream, with the result that dilution factor may be low, and also high temperature may result in low solubility of oxygen. This river can consider as healthy as long as with minimum DO $5 \mathrm{mg} / \mathrm{l}$. This might be a reason for the survival of special fishes in this river.

Fig 9 shows the temporal and spatial distribution of the maximum EC. The values of electrical conductivities obtained from all the surface water samples ranges from 30 to $480 \mu \mathrm{mhos} / \mathrm{cm}$ with a mean value of $124.68 \mu \mathrm{mhos} / \mathrm{cm}$. The maximum value of EC observed was $480 \mu \mathrm{mhos} / \mathrm{cm}$ in Site IV during nonmonsoon 2015. During nonmonsoon 2014 , most of the sites shows comparatively high values of EC than 2015 .

Fig10 shows the temporal and spatial distribution of the maximum TDS. The mean TDS of samples collected during the years 2013, 2014 and 2015 were 54.17, 71.11 and $38.59 \mathrm{mg} / 1$ respectively. Maximum value of TDS recorded was $320 \mathrm{mg} / \mathrm{l}$ in site III in monsoon 2014. The desirable limit of TDS in drinking water is $500 \mathrm{mg} / 1$ [13]. Minimum TDS was observed during the year 2015 Compared with the year 2013 and 2014.

Fig 11 shows the temporal and spatial distribution of the maximum TC. High value of TC $1470 \mathrm{MPN} / 100 \mathrm{ml}$ shows in Site III during monsoon 2014 and the lowest value of TC was $27 \mathrm{MPN} / 100 \mathrm{ml}$. It means that domestic pollution was comparatively high in all the sites in this river. It was very high in 2014 compared with the year 2015. The recoded value of TC during the study time crossed the WHO and IS limit (Absence or 10MPN/100ml).It may be the result of improper human activity. All the other parameters analyzed were lies in between the WHO and IS limit.

Maximum mean value of pesticides of $\beta$ Endosulphan $(0.06 \mu \mathrm{g} / \mathrm{L})$ and of Lindane $(0.04 \mu \mathrm{g} / \mathrm{L})$ in surface water samples were observed in site IV (Pariyaram) during monsoon 2015. Other values were BDL. Most of the OCPs were ND in surface water samples. Lindane, however, has not been produced or used in the United States for more than 20 years [16]. The solubility of Lindane in water is $10 \mathrm{mg} / \mathrm{l}$ and reported half-life is of 18 hours. Lindane is "Moderately Hazardous" pesticide according to WHO and USEPA. The presence of high concentration of Lindane can negatively affect the nervous system producing a range of symptoms from headaches and dizziness to convulsions and more rarely death (Agency for Toxic Substances and Disease Registry 2005). Pesticides in surface water do not remain at their target site but it distribute to the environment via soil percolation, surface runoff affecting abundance and diversity of non-target species producing complex effect on the ecosystems [15].

The analysis results of sediment samples collected from the various sites of Chalakkudy River have shown the presence of residues of organochlorine pesticides. Table4. Showst mean concentration $(\mu \mathrm{g} / \mathrm{L})$ OCP's in surface samples from the study area. Presence of pesticides $\beta$ Endosulphan and Lindane were observed in surface water collected from Pariyaram site. The maximum mean concentration of $\beta$ Endosulphan and Lindane in surface water recorded 
during the study period were $.04 \mu \mathrm{g} / \mathrm{L}$ and $.06 \mu \mathrm{g} / \mathrm{L}$ during monsoon 2015.

Table 5.shows the mean concentration $(\mu \mathrm{g} / \mathrm{gm})$ OCP's in sediment samples from the study area Some of the sediment samples from different sites were shows the presences of low concentrations $(0.06 \mu \mathrm{g} / \mathrm{L}$ to $0.04 \mu \mathrm{g} / \mathrm{L})$ of a few pesticides in the Chalakudy river basin. During this study sediment samples collected from Kanjirappilly site, Pariyaram site, Chalakudy and in Mamrakadavu site were detected the presence of $\beta$ Endosulphan. Sediment collected from Pariyaram site shown the maximum presence of $\beta$ Endosulphan, the mean value was $0.45 \mu \mathrm{g} / \mathrm{gm}$ in during summer 2014. Most of the values were ND. The values range from BDL to $0.4 \mu \mathrm{g} / \mathrm{gm}$. That may be by the application in vegetables and in plantations and by agricultural runoff [20]. It had been observed that the presences of pp-DDT, $\beta$ Endosulphan, $\alpha$ BHC, Dicofol and Lindane in the bottom sediment.

Endosulphan is highly toxic pesticide in EPA toxicity. It may be slightly toxic via inhalation and it is Carcinogenic. The solubility of Endosulphan is $0.3 \mathrm{mg} / \mathrm{l}$ with a half-life of 50 days in soil and 5 weeks in water $\beta$ isomer of Endosulphan has longer half-life i.e. 150 days under neutral conditions. The beta isomer is considered to be more toxic than the alpha-isomer $[16,17]$. So Endosulfan is banned in many countries.

Maximum mean value of pp-DDT was $0.48 \mu \mathrm{g} / \mathrm{gm}$ in the sediment sample collected from site III during Monsoon 2015. Presence of pp-DDT ranges from BDL to $0.48 \mu \mathrm{g} / \mathrm{gm}$. Site I, Site III, Site V and Site VI shows the presence of pp-DDT in the sediment samples. The maximum values were $0.48,0.28,0.274$ and 0.382 $\mathrm{mg} / \mathrm{kg}$ respectively during 2015 . Site I, Site III and Site VI also observed the presence of pp-DDT during Monsoon 2015. DDT is classified as moderately toxic by US National toxicological program and moderately hazards by WHO. DDT is highly toxic to aquatic life like fishes and it can be bioaccumulation leading to cumulative and synergistic effects on the endocrine systems [14]. Higher concentration of DDT leads to Neuropsychological and Psychiatric symptoms [10].

The presence of Dicofol (Kethane) and Lindane detected in bottom sediment of Site V, Site VI and in site IX. The maximum mean values of Dicofol were $0.24 \mu \mathrm{gm} / \mathrm{gm}, 0.11 \mu \mathrm{gm} / \mathrm{gm}$ and 0.45 $\mu \mathrm{gm} / \mathrm{gm}$ respectively. The maximum mean concentration of Dicofol observed in the sediment collected from Vynthala Site $(0.45$ $\mu \mathrm{gm} / \mathrm{gm})$. In Pariyaram site bottom sediment samples were determined the presence of Dicofol during non monsoon 2015. The values range from BDL to $0.24,0.82 \mu \mathrm{gm} / \mathrm{gm}$. The maximum concentration of Lindane observed in the sediment sample was $0.82 \mu \mathrm{gm} / \mathrm{gm}$ and minimum was BDL.

In Site I and Site II observed the presence of $\alpha \mathrm{BHC}$ and maximum presence was $1.5 \mu \mathrm{gm} / \mathrm{gm}$. The concentration ranges from BDL to $1.5 \mu \mathrm{gm} / \mathrm{gm}$ during the study period. It is a high value according to Canadian guide lines of sediment quality [23]. This is the one and only site observed the presence of $\alpha \mathrm{BHC}$. $\alpha \mathrm{BHC}$ is a byproduct of the production of the insecticide Lindane $(\gamma-\mathrm{HCH})$ and it is typically still contained in commercial grade Lindane used as insecticide[16]. It is sparingly soluble in water. The monsoon floods carry these types of pollutants from nearby fields in to the river.

\section{Conclusion}

The study intends to find the water quality and load of pesticide contamination in the study area. Water quality of a river changes by different physical, chemical and biological processes. The concentrations of the pesticide contaminants in surface water samples were very low as compared to the concentrations in sediment samples. In certain stretches, mainly at middle stretch; sediment and surface water were slightly contaminated by pesticides especially with $\beta$ Endosulphan, and pp-DDT. Sediment collected upper stretches near vazhachal and vettilappara sites observed the presence of $\alpha B H C$. During the study spatial and temporal distributions of parameters revealed that was revealed that $\mathrm{pH}$, EC, TDS, and Chlorides have been affected by seasonal variations. And seasonal fluctuation in TC is visible and increase in TC leads to increase in bacterial Count those results in water borne diseases, and can affect water quality in future. In the case of Chalakudy river it was revealed that enough DO is present in this river water samples collected from study area. Overall it can be clear that domestic pollution is existing in this river in the form of E.coli. Physicochemical parameters and analysis of pesticides in this area would be useful in future for identify the culture and for ecology of this river.

\section{Acknowledgement}

The authors would like to express their sincere thanks to higher education department, government of Kerala for financial support.

\section{References}

[1] American Public Health Association (APHA), 2012: Standard methods for Examination of waste and waste water, $22^{\text {nd }}$ Edition.

[2] Aderonke Adetutu Okoya, Aderemi Okunola Ogunfowo kan,Olabode Idowu Asubiojo, and Nelson Torto, "Organochlorine Pesticide Residues in Sediments and Waters from Cocoa Producing Areas of Ondo State, Southwestern Nigeria", ISRN Soil Science Volume 2013, Article ID 131647, 12 pages.

[3] Anju Agrawal1, Ravi S. Pandey, Bechan Sharma and Suredra Nath Balika, Water Pollution with Special Reference to Pesticide Contamination in India, J. Water Resource and Protection, 2010, Volume 2, 432-448.

[4] Bureau of Indian standard Specifications for drinking Water IS: 10500

[5] Derek Muir, Rainer Lohmann,Water as a new matrix for global assessment of hydrophilic POPs, 2013,Trends in Analytical Chemistry, 2013, 12-172.

[6] Govindasamy C., Kannan L. and Azariah, (2000), Seasonal variations in physico chemical properties and primary production in the central water bio-tops of Coromandal coast India, Journal of Environmental Biology, 26 (1), pp 17

[7] Haider, Waris Al \& Sajjad Haydar,A Review of Dissolved Oxygen and Biochemical Oxygen Demand Models for Large Rivers Husnain , Pak. J. Engg. \& Appl. Sci. Vol. 12 Jan.,2013, p. 127-142.

[8] Ibrahim's. And Abdullahi, B.A. A suvey of Phytoplankton and evaluation of some physicochemical properties of Challawa River, Kano state, Nigeria, Best Journal, 6(1) 2009, 76-82.

[9] James E Cloern, Turbidity as a control on phytoplankton biomass and productivity in estuaries, continental Self Research, 1987Vol 7, pp 1.367-1381.

[10] Jin-Song Liu, jia-Ping yan , Liang-jiXu,' 'Comprehensive analysis on water quality of Nihe river in Panji mining area of Huainam", school of Earth and environment Science, an HUi University of Science and Technology.

[11] Kihampa Harieth Heller, Pesticide residue in four rivers running through an intensive agricultural area,Kilimanjaro,Tanzani, Journal of Science.Environ.mange, June 2011,Vol.15(2), 307-316.

[12] Maya.K., studies on the nature and chemistry of sediments and water of Periyar and Chalakudy rivers, kerala, India. 2005.

[13] Nhapi,U.G, Wali,B.K, Uwonkunda, H.Nsengimana, N.Banada and R.Kimwaga, Assessment of water pollution levels in the $\mathrm{Ny}$ bugogo Catchment,Rwanda, Open Environmental Engineering Journal 2011, Vol. 4, 40-60.

[14] P.K.Mutiyar and A.K.Mitta, Status of organochlorine pesticides in Ganga river basin: anthropogenic or glacial? 2013 Drink. Water Eng. Sci., 6, 69-80.

[15] Punmia B.C., Ashok.K.J, Arun K.J.,waste water engineering,Lakshmi Publications, 1988

[16] RO Aqofolu, OS Fatoki, Persistance of organochloine pesticides in fresh water systems and sediments from eastern cape, South Africa, South Africa Water S.A 2004; 29(3).

[17] Sait Bulut, Sevim Feyza ErdoðmuP, Muhsin Konuk and Mustafa Cemek, The Organochlorine Pesticide Residues in the Drinking Waters of Afyonkarahisar, Turkey, Ekoloji 2010,19, 74, 24-31. 